\title{
PERFORMANCE OF HERBAL EXTRACTS ON DISEASED FISH
}

\author{
M. N. Alam, G. U. Ahmed* and M. B. R. Chowdhury \\ Department of Aquaculture, Faculty of Fisheries, Bangladesh Agricultural University, Mymensingh-2202, \\ Bangladesh
}

\begin{abstract}
An experiment was conducted for a period of 28 days to observe the effect of plant extracts on recovery of fish diseases. The experiment was carried out in mini pond (1.75 decimal) behind the Fisheries Faculty in BAU, Mymensingh. Twelve hapas (3 $\times 2 \times 1.5$ sq.ft.) and five studies were conducted with control hapa with 3 treatments and two replicates each. Four medicinal plant products were collected and prepared. In study 1 fishes were treated with Neem Seed Oil, study 2 with Kalojira Seed Oil, study 3 with Neem Leaf Extract, study 4 with Mahogoni Seed Oil and the control hapa was provided with normal feed. The treatments were practiced as $2 \mathrm{ml}, 4 \mathrm{ml}$ and $6 \mathrm{ml}$ per $\mathrm{kg}$ feed. At the beginning of the experiment, fishes had red spots on dorsal and caudal region, scale missing, large abrasions and black to grayish spots. In Kalojira Seed Oil (study 2) treated fish, spots and lesions were totally recovered in $\mathrm{T}_{2}$ and $\mathrm{T}_{3}$ whereas in $\mathrm{T}_{1}$ there were traces spots at the end of the experiment. However, in Neem Seed Oil and Neem Leaf fine extract treated fish (study 1 and study 3), injury, abrasions and lesions were almost healed up in $T_{3}\left(6 \mathrm{ml} / \mathrm{kg}\right.$ feed) and moderate recovery in $T_{2}$ and $T_{1}$. In Mahogoni Seed Oil (study 4) treated fish, ulcers and lesions were reduced in size but existed distinctly in all the treatments at the end of the experiment. In control study (study 5) injury and abrasions had no recovery but remained almost similar till the end of experiment. Thus it was found that Kalojira Seed Oil performed best recovery (90-95\%) followed by Neem Seed Oil (78-84\%), Neem Leaf fine extract (70-75\%) and poor performance was observed with Mahogoni Seed Oil extract (35-40\%). So, kalojira seed oil was the best performed herb and $\mathrm{T}_{3}$ $\left(6 \mathrm{ml} / \mathrm{kg}\right.$ feed) was the best dose followed by $\mathrm{T}_{1}$ and $\mathrm{T}_{2}$.
\end{abstract}

Key words: Herbs, Extracts, Fish, Disease

\section{INTRODUCTION}

Aquaculture is one of the important sectors contributing significantly in the national economy of Bangladesh. For increased production and profit, fish farmers are encouraged towards intensification of culture system. In such practice of fish/shrimp farming, disease becomes major problem. Disease is one of the most important problems of fish production both in culture system and wild condition of Bangladesh (Rahman and Chowdhury, 1996). Fishes have been suffering from many diseases such as epizootic ulcerative syndrome (EUS), tail and fin rot, fungal, parasitic and bacterial infections (Chowdhury, 1999). With the outbreak of EUS in 1988, Channa sp., Puntius sp., Anabas sp., Clarias sp., and other indigenous species of fish are seriously affected (Barua et al., 1991). Thus to prevent and control of fish diseases, treatment trials has become an essential component of fish production.

Chemotherapy has progressed internationally for treating the most diversified infectious disease of fish (Shieszko, 1959). However, there are problems associated with the use of such chemicals. It was the demand of the time to look for alternative means of commercial synthetic drugs. Medicinal plants are vital source of drugs from the ancient time holding the scenario of the Indian system of medicine (Sharma et. al., 2009). According to Ghoni (1998) medicinal plants are rich sources of bioactive compounds and thus serve as important raw materials for drug production. In Bangladesh, different kinds of medicinal herbs are available which grow in roadside, small jungles are fellow lands and most of them are cultivable with very low cost. The application of herbal medicine has grown in laboratories and in papers with little field practice. Some farmers have experienced this treatment method as crude extract of herbs (Ha Thu et al., 2011). It is thus necessary to apply both the crude and fine extract of herbs which can carry more specific and confirm use of herbal medicine in laboratory and field at large scale. Thus the objective of present study was to observe the use of various medicinal plant products against fish diseases.

\section{MATERIALS AND METHODS}

The experiment was carried out for a period of 28 days from 07 March to 04 April 2012, to observe the effect

*Corresponding e-mail address: giasa50@gmail.com

Copyright $@ 2014$ Bangladesh Society for Veterinary Medicine

All rights reserved 0315/2014 


\section{N. Alam and others}

of plant extracts on recovery of fish diseases. The experiment was carried out in mini ponds (1.75 decimal) behind the Fisheries Faculty in BAU, Mymensingh. Thirteen hapas were set with size of $3 \times 2 \times 1.5$ sq.ft with five studies (Fig. 1). Four types of herbal products medicines and a control were used in the present investigation. In study 1 fishes were treated with Neem Seed Oil, study 2 with Kalojira Seed Oil, study 3 with Neem Leaf Extract, study 4 with Mehagoni Seed Oil and study 5 (control hapa) was provided with normal feed. The treatments were designed as $2 \mathrm{ml} / \mathrm{kg}$ feed, $4 \mathrm{ml} / \mathrm{kg}$ feed and $6 \mathrm{ml} / \mathrm{kg}$ feed for each study. Each study had 3 treatments $\left(\mathrm{T}_{1}, \mathrm{~T}_{2}\right.$, and $\mathrm{T}_{3}$ ) with two replicates $\left(\mathrm{R}_{1}, \mathrm{R}_{2}\right)$ in each. Diseased fish were collected from a research pond of the Fisheries Faculty, BAU, Mymensingh. The fish species were Sharputi (Puntius sarana) $\left(\mathrm{T}_{1}\right.$ and $\mathrm{T}_{2}$ ) and Rui (Labeo rohita) $\left(\mathrm{T}_{3}\right.$ and $\mathrm{T}_{4}$ ) affected by EUS and red spot diseases. The selected medicinal plants were Neem (Azadirachta indica), Kalojira (Nigella sativa) and Mahogoni (Swietenia mahagoni). Three semi crude extracts such as Neem seed oil, Kalojira seed oil, Mehagoni seed oil and one solvent extract (Neem leaf) were used in the present investigation. Neem seed oil and kalojira seed oil were collected from a grocer shop, Choto bazaar, Mymensingh. Mehagoni seed oil was collected from Rampal, Bagerhat. The Neem leaves were dried in the sunlight and prepared into powder form by using grinder. This powder was extracted into fine form by using ethanol in a soxhlet apparatus in the Agri-chemistry Laboratory, Faculty of Agriculture, BAU, Mymensingh. Then it was stored in the refrigerator. The feed were supplied on earthen trays during experiment (Fig. 2). For clinical observations sampling were done at seven days interval (Fig. 3). Water quality parameters like temperature, $\mathrm{pH}$, dissolved oxygen and ammonia were measured by using test kit from Welltech Biotchnology Products Co. Ltd. and Vet Superior Aquaculture Co. Ltd. Thailand. For clinical observation, fishes were examined externally for any injury, infections and diseases.

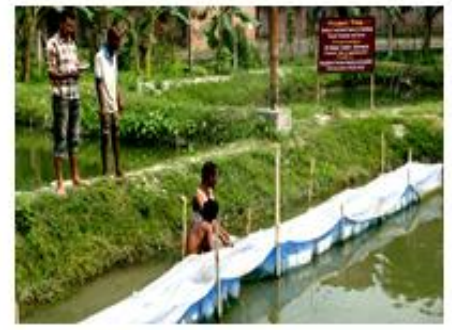

Fig. 1. Experimental setup of Hapas.

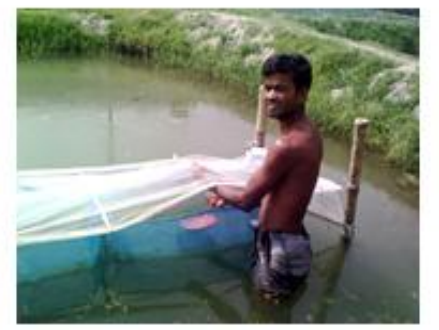

Fig. 2. Feeding on earthen Fig. 3. Sampling (clinical obsertray.

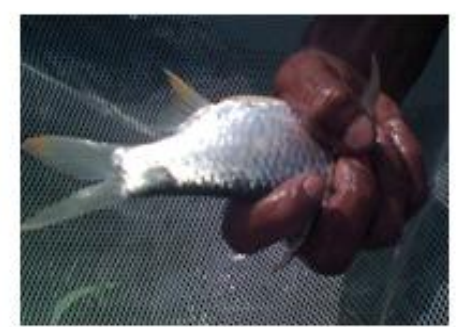

vation) during experiment.

\section{RESULTS}

In study 1, at the beginning of the experiment fish had several red spots on lateral sides, large brownish abrasions near tail and scale missing with red spots near pelvic region (Fig. 4). After first week in $\mathrm{T}_{1}$ red wound become smaller in size, in $\mathrm{T}_{2}$ large brownish wound become smaller in size and color become grey to light and in $\mathrm{T}_{3}$ red spots turned to smaller in size. After second week, in $\mathrm{T}_{1}$ red wound become fade and reduces red color, in $\mathrm{T}_{2}$ and $\mathrm{T}_{3}$ no changes were recorded. At the end of the experiment, in $\mathrm{T}_{1}$ only one small red spots was present among the several spots and the rest almost recovered (Fig. 5), in $\mathrm{T}_{2}$ the wound become small blackish spot and in $\mathrm{T}_{3}$ spots healed up to give almost normal appearance (Fig. 6). The recovery rate was $78-84 \%$.

In study 2, at the beginning of the experiment, fishes had blackish to grayish spots on the dorsal side near dorsal fin and transparent large round lesion at caudal base (Fig. 7). After first week, in $\mathrm{T}_{1}$ mild blackish to grey spots faded, in $\mathrm{T}_{2}$ red spots became black and in $\mathrm{T}_{3}$ large lesions turned to blackish and smaller in size. After second week, fish in $\mathrm{T}_{1}$ had no change, in $\mathrm{T}_{2}$ black spots recovered to smaller in size, in $\mathrm{T}_{3}$ the blackish spots reduced in size and turned to grey. At the end of the experiment, in $T_{1}$ fishes were almost recovered to healthy appearance (Fig. 8) and in $\mathrm{T}_{2}$ and $\mathrm{T}_{3}$ fishes were totally recovered (Fig. 9). The recovery rate was 90-95\%.

In study 3 , at the beginning of the experiment fishes had reddish to grayish lesions extended throughout the whole lateral side, red lesion also found at caudal base (Fig. 10). After one week of the Neem Leaf Extract treatment, in fishes of $T_{1}$ there was no improvement, in $T_{2}$ there were some recovery except at the caudal base and in $\mathrm{T}_{3}$ the extended ulcers reduced in size and slender After two week, in-T-1 there were no improvement, in 
T-2 was very slow recovery and in $\mathrm{T}_{3}$ there was moderate recovery (Fig. 11). At the end of the experiment, in $\mathrm{T}_{1}$ there were no significant changes, in $\mathrm{T}_{2}$ recovery was still slow and in $\mathrm{T}_{3}$ the fishes were almost recovered (Fig. 12). The recovery rate was $70-75 \%$.

In study 4, at the start of the experiment the fishes had scale loss in the affected area, several fade black spots on lateral line, dorsal and tail region and deep reddish ulcers throughout the lateral side towards the caudal base (Fig. 13). After one week of the Mahagoni Seed Oil treated fishes has no healing in all the treatments. After second week, in $T_{1}$ and $T_{2}$ there were no recovery, in $T_{3}$ there were some recovery with black spots turned to smaller in size. At the end of the experiment, in $\mathrm{T}_{1}$ and $\mathrm{T}_{2}$ there were still almost no healing (Fig. 14 ), however, in $\mathrm{T}_{3}$ the fishes were healed considerably (Fig. 15). The recovery rate was 35-40\%.

In study 5 (control), at the start of the experiment fishes had reddish lesions extended throughout the lateral side and red lesion found at caudal base. At the end of experiment, there was no healing or recovery of the affected fishes in all the treatments (Fig. 16, 17 and 18).

In the present investigation, the values of water temperature were ranged from $26.5^{\circ} \mathrm{C}$ to $29^{\circ} \mathrm{C}$ in the morning and $29.5^{\circ} \mathrm{C}$ to $31^{\circ} \mathrm{C}$ in the afternoon. The minimum value of water temperature was $26.5^{\circ} \mathrm{C}$ recorded at the beginning of the experiment and the highest value of water temperature was $31^{\circ} \mathrm{C}$ recorded at the end of the experiment. $\mathrm{P}^{\mathrm{H}}$ values of water were ranged from 7.5 to 8.5 in the morning and 8.0 to 8.5 in the afternoon during the experimental period. Dissolve oxygen was ranged from 4.5 to $6 \mathrm{ppm}$. The highest dissolve oxygen was 6.5 ppm, the lowest was $4.5 \mathrm{ppm}$.

\section{DISCUSSION}

In the present study, at the beginning of the experiment, clinically it was observed that, the fishes had red spots on lateral side, large brownish abrasions near tail, scale missing and red spots near pelvic region. In Neem treated studies (studies 1 and 3) after first week there were almost no recovery in $\mathrm{T}_{1}$, after second and third week in Neem seed oil treated fish, red wound became smaller in size in, large brownish wound turned to grey in $T_{2}$ and at the end of the experiment in $\mathrm{T}_{3}$ there were complete recovery to yield almost normal appearance. In study 3 , Neem leaf extract treated fish had also similar pattern of recovery in all the treatments at the end of the experiment. Anon (1994) found that a paste prepared from ground Neem leaf and turmeric ( $C$. longa) was effective against EUS. Campbell et al. (2001) found that Neem extracts as well as malachite green, ash, potassium permanganate had a strong anti-fungal property against $A$. invadans. As EUS occurred mostly due to Aphanomyces fungus in Bangladesh (Ahmed et al., 2007). Thus it could be mentioned that extracts of Neem seed and Neem leaf could help in recovery from EUS in the present study. Khan (2001) also mentioned that, Neem could be potential as a preventive treatment of EUS and recommended for use in small ponds. The dried bark and leaves of Neem contain a bitter amorphous resin, an alkoholid margisine and margosic acid and used as an anticeptic and germicide (Vallachira, 1998). Neem seed oil has been shown to exert to antibacterial activity, biological activity of some Neem compounds included immunostimulant activity, antiviral, antifungal, antiulcer activity (Biswas et al., 2002). Rahman, (2007) investigated that mixture of Akand and Neem showed the prominent effect with $86.6667 \% \pm 3.3333$ recoveries against the infectivity of bacterial pathogens.

In study 2, the fishes had blackish to grayish spots on the dorsal side near dorsal fin and transparent large round lesion on caudal base at the beginning of the experiment. At the end of the experiment, it was found that fishes were almost recovered in $T_{1}$, totally recovered in $T_{2}$ and $T_{3}$ at the end of experiment. This could be due to black cumin seed possessed antifungal activity (Islam et al., 1989). According to Khan (1999) stated that, black cumin (kalojira seed) seed has many medicinal properties such as bronchodilatory, hypotensive, antibacterial, antifungal, analgesic, anti-inflamatory and immunopotentiating and were universally accepted as a panacea. The volatile oil of the seed possessed antibacterial activity against multiple drugs resistant bacteria including vibrio cholerae (Ferdous et al., 1992). It also possessed antimicrobial, antifertility, anticancer (tumor inhibiting) and cardio vascular activities (Siddique and Sharma, 1996). Thus due to the mentioned immense qualities of kalojira, fish diseases and abrasions were recorded within a month.

In Mahogoni seed oil treated fish (study 4), fishes had no injury recovery at the end of third week; However at the end of the experiment there were some healing (50\%) in $\mathrm{T}_{3}$, whereas, in $\mathrm{T}_{1}$ and $\mathrm{T}_{2}$ clinical signs and injury still existed. Thus Mahogoni seed oil exhibited poor performances in respect of epidermal wound healing of Thai Sharputi and Rui. Whereas, in study 5 (control), at the end of experiment EUS and epidermal wounds were 


\section{N. Alam and others}

existed similar and there were almost no healing. Some of the fishes of control group were died (40\%) after third week of the present study.

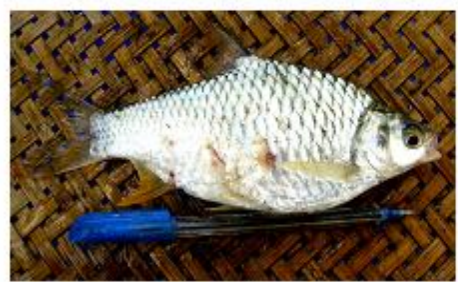

Fig. 4. Pho tograph of Thai Sharputi at the start of the study 1.

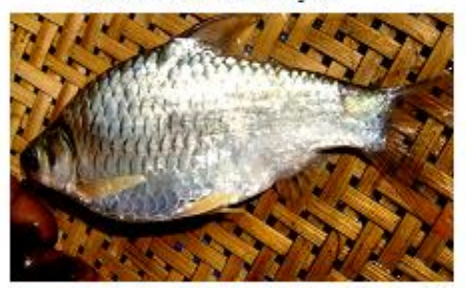

Fig. 7. Photograph of Thai Sharputi at the start of the study 2 .

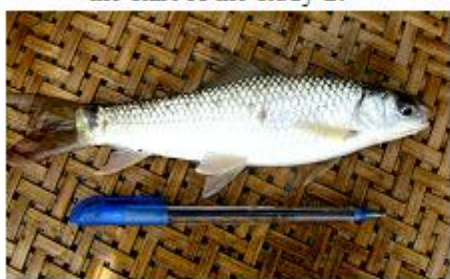

Fig. 10. Photograph of Rui at the start of the study 3 .

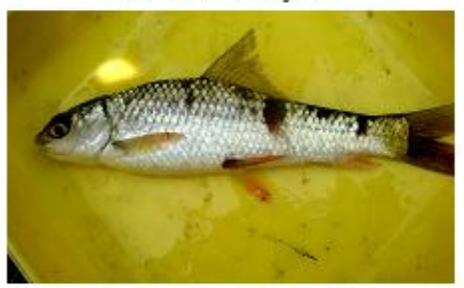

Fig. 13. Photograph of Rui at the start of the study 4 .

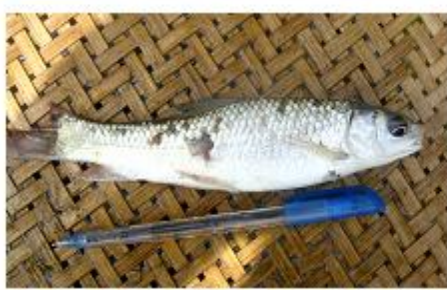

Fig. 16. Photograph of Rui at the end of the study 5 (control).

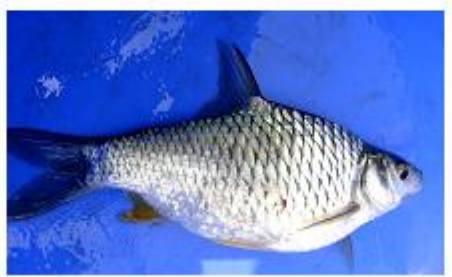

Fig. 5. Photograph of Thai Sharputi at the end of the study 1 in $\mathrm{T}$.

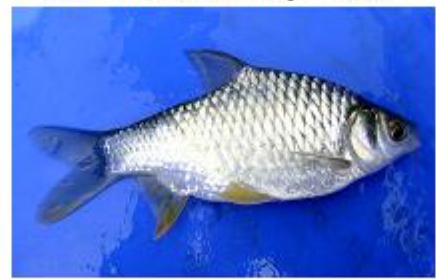

Fig. 8. Photograph of Thai Sharputi at the end of the study 2 in $\mathrm{T}_{1}$.

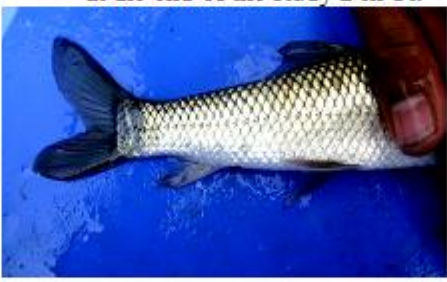

Fig. 11. Photograph of Rui at the end of the study 3 in $T_{2}$.

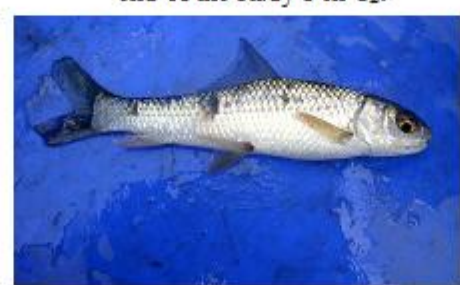

Fig. 14. Photograph of Rui at the end of the study 4 in $T_{2}$.

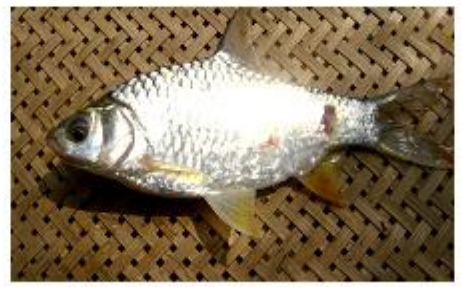

Fig. 17. Photograph of Sharputi at the end of the study 4 (control).

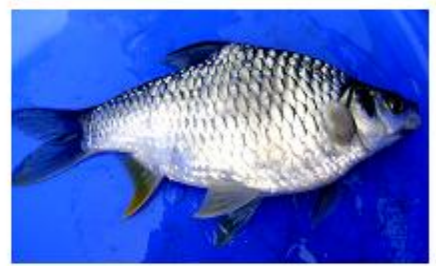

Fig. 6. Photograph of Thai Sharputi at the end of the study 1 in $\mathrm{T}$.

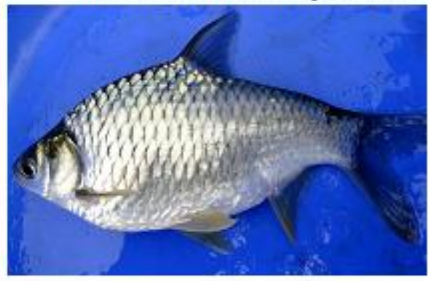

Fig. 9. Photograph of Thai Sharputi at the end of the study 2 in $\mathrm{T}_{3}$.

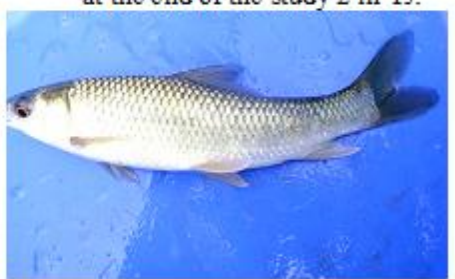

Fig. 12. Photograph of Rui at the end of the study 3 in $T_{3}$.

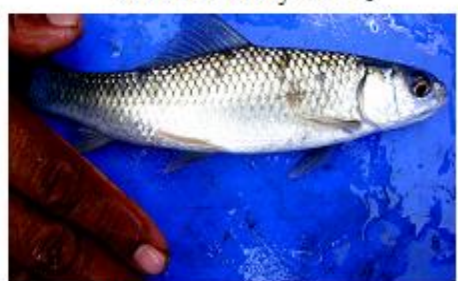

Fig. 15. Photograph of Rui at the end of the study 4 in $T_{3}$.

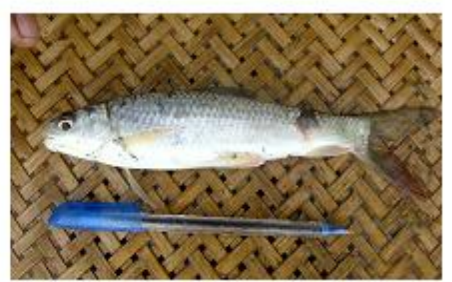

Fig. 18. Photograph of Rui at the end of the study 4(control). 
Medicinal plant thus could be used with feed as an alternative control measure against fish diseases. Kalojira seed oil could be a suitable drug for the healing of external wounds of fish followed by Neem seed oil. However, fishes treated with Neem leaf extract also exhibited better performance for disease (EUS) recovery of fish and Mehogoni seed oil were found poor performance for the healing of fish disease. Whereas Neem seed oil exhibited satisfactory disease recovery than study 3 and 4.

Water quality parameters are important considerations of health issues in fishes. In the present study, the recorded values of water temperature were ranged from $26.5^{\circ} \mathrm{C}$ to $29^{\circ} \mathrm{C} \mathrm{C}$ in the morning and $29.5^{\circ} \mathrm{C}$ to $31^{\circ} \mathrm{C}$ in the afternoon in April. Ahmed et al. (2009) observed that the value of average temperature was $31.5^{\circ} \mathrm{C}$ during April and May from four oxbow lakes of the Mymensingh area. In contrast the lowest temperature was $17^{\circ} \mathrm{C}$ recorded in January. Ahmed et al. (2007) measured water temperature ranged from $19.5^{\circ} \mathrm{C}$ to $29.5^{\circ} \mathrm{C}$ from two different farms of Mymensingh district. In the present study, the $\mathrm{P}^{\mathrm{H}}$ value of water was ranged from 7.5 to 8.5 in the morning and 8 to 8.5 in the afternoon during the experimental period. Wahab et al. (1995) reported that $\mathrm{pH}$ was always around 6.0 in BAU campus, Mymensingh. Gosh (2006) observed that in private fish farm of Mymensingh, Thai sharputi and silver carp were more affected (clinically and histologically) in December and January when $\mathrm{p}^{\mathrm{H}}$ were minimum level (6.5). In the present study the highest dissolve oxygen was $6.5 \mathrm{ppm}$ and the lowest was $4.5 \mathrm{ppm}$. Wahab et al. (1995) observed low dissolved oxygen content (2.0 ppm to $7.2 \mathrm{ppm})$ during their experiment in BAU campus, Mymensingh. DoF (1996) reported that the dissolved oxygen range of a suitable water body for fish culture would be 5 to $8 \mathrm{ppm}$. So it can be mentioned that the observed values of water quality parameters were within suitable range of fish culture in the present study.

\section{CONCLUSION}

The present study provides some useful information regarding the efficacy of medicinal herbs against fish disease. Out of four medicinal plant products used have Kalojira seed oil showed better disease recovery followed by Neem seed oil and Neem leaf extract. Mahogoni seed oil exhibited poor recovery of diseased fishes.

\section{REFERENCES}

1. Ahmed GU, Ferdous MJ and Hossain MS (2009). Disease occurrence and histopathology of catfish and snakehead in oxbow lake fisheries of Bangladesh. Journal of Subtropical Agricultural Research and Development 7(3): 638644.

2. Ahmed GU, Dhar M, Khan MN and Choi JS (2007). Investigation of diseases of Thai Koi, Anabas testudineus $(\mathrm{BLOCH})$ from farming conditions in winter. Korean Journal of life Science 17 (10): 1309-1314.

3. Anon (1994). Indigenous treatment for fish disease. The Hindu, 9 November 1994.

4. Barua G, Banu ANH and Khan MH (1991). An investigation in to the prevalence of fish disease in Bangladesh during 1988. Bangladesh Journal of Aquaculture 11-13: 27-29.

5. Biswas K, Chattopadhyay I, Banerjee RK and Bandyopadhyay U (2002). Bioligical activities and medicinal properties of Neem (Azadiachta indica). Current Science 82 (11): 1336-1345.

6. Campbell RE, Lilley JH, Tauhid V, Panyawachirab and Kanchanakhan (2001). In vitro screening of novel treatments for Aphanomyces invadans. Aquaculture Research 32: 6-33.

7. Chowdhury MBR (1999). Bacterial involvement in fish disease in Bangladesh. Presented at the International Symposium on Disease in Marine Aquaculture, October 3-6, 1997, Hiroshima, Japan. Abstract III, p. 2-24.

8. Do F (1996). Fish Fortnight Compendium. 10-24 August 2002. Department of Fisheries, Matsha Bhaban, Dhaka.

9. Ferdous AJ, Islam SN, Hasan CM and Ahmed ZU (1992). In: Ghani, A. 2003. Medicinal plants in Bangladesh. Asiatic Society of Bangladesh, p. 319 .

10. Ghani A (1998). Medecinal plants Bangladesh. Asiatic Society of Bangladesh, p. 460.

11. Ghosh NC (2006). Comparative Materia Medica Hannemann Publ. Co. Pvt. Ltd. Colicata, India, p. 347-353.

12. Ha Thu, Malody M, Barbara M (2011). Using herbal in aquaculture. Aquaculture Hub<http// www.aquaculturehub.org/profiles/blogs/using-herbal-in-aquaculture> (5 December, 2011).

13. Islam SN, Hasan M, Hasan CM and Malek MA (1989). In Ghani, A. 2003. Medicinal plants in Bangladesh. Asiatic Society of Bangladesh, p. 319.

14. Khan MA (1999). Chemical composition and medicinal properties of Nigella sativa Linn. Inflammopharmacology 7 (1): 15-35.

15. Khan MH (2001). Epidermiological studies on epizootic ulcerative syndrome (EUS) in Bangladesh. PhD. Thesis, Institute of Aquaculture, University of Stirling, Scotland, UK, p. 250. University, Mymensingh, Bangladesh, p. 73.

16. 


\section{N. Alam and others}

17. Rahman MM and Chowdhury MBR (1996). Isolation of bacterial pathogen causing an ulcer disease in farmed carp fishes of Mymensingh. Bangladesh Journal of Fisheries 19: 103-110.

18. Rahman T (2007). Efficacy of selected chemotherapeutic and medicinal plants against common microbial fish pathogens. An MS Thesis, submitted to the Department of Aquaculture, Bangladesh Agricultural University, Mymensingh, Bangladesh p. 85.

19. Sharma NK, Ahirwar D, Jhade D and Gupta S (2009). Medicinal and pharmacological potential of Nigella sativa. A Ethnobotanical Review 19: 946-955.

20. Siddique AA and Sharma PKR (1996). In Ghani, A.2003. Medicinal plants in Bangladesh. Asiatic Society of Bangladesh p. 3198.

21. Snieszko SF (1959). Antibiotics in fish diseases and fish nutrition (Leetown, W. Va. S. Fish and Wildlife Serv., Estern Fish Disease Lab). Antibacterial Chemotherapy 9: 541-545.

22. Vallachira A (1998). Veterinary Materia Medica. First edition. Jaypee Brothers Medical publishers Ltd. New Delhi, India, p. 229.

23. Wahab MA, Ahmed ZF, Aminul Islam M and Rahmatullah SM (1995). Effect of introduction of common carp, Cyprinus carpio (L) on the pond ecology and growth of fish in poly culture. Aquaculture Research 26: 619-628. 